\title{
Jolly, Joanna. (2019). Red River Girl: The Life and Death of Tina Fontaine. New York: Penguin Random House Canada.
}

\author{
Reviewed by Andrea Reimer, MacEwan University
}

Joanna Jolly’s book titled, "Red River Girl: The Life and Death of Tina Fontaine”, is a true crime book that tells the heartbreaking story of missing and murdered fifteen-year-old Tina Fontaine in Winnipeg Manitoba. Tina Fontaine was described as a loving and caring young woman who went through an extremely tough time after the loss of her father. Jolly's book walks the reader through the life choices and experiences Tina Fontaine had in the few months leading up to her murder. The book focuses on finding justice for Tina and her loved ones. Jolly tells Tina's story through the themes of crime, betrayal, support and love and the seeking of justice.

Jolly describes many examples of the love and support Tina received while growing up as well as after her death. Tina Fontaine's death sparked outrage in the city of Winnipeg, which brought together many people to show their love and support. Tina grew up on the Sagkeeng First Nations Reserve. Tina was raised by her father and then great aunt Thelma Favel, who loved her as her own daughter. Thelma and her husband Joe loved and supported Tina from a young age giving her a stable home and switching schools to better her education. Tina was loved by many family members and friends such as Larry Dumas, who had shown his care for her when he brought her back to the Reserve after running away to Winnipeg to visit her mother. Joseph Nanacowap was another friend from the city, who allowed her to sleep at his place from time to time. Tina's 
family members in the city of Winnipeg opened their doors to her, although she did not choose to stay with any. Steve Whitehurst who was a family friend to Tina also allowed her to stay with him, but he had stated that, "You can't have your boyfriend over twenty-four seven, and I need to know where you are." (Chapter 5). Tina also had the love of Sergeant John O'Donovan, who went to extensive lengths of hard work to bring justice to Tina and her loved ones.

Jolly describes how Tina was exposed to crime both in her home community of Sagkeeng and when she came to Winnipeg. Tina was exposed to crime long before she was living in Winnipeg. Tina's guardian was Thelma Favel as her birth mother Valentina Duck struggled with drugs and alcohol and began selling her body on the streets of Winnipeg from a young age. Tina's motive for visiting the city was to be with her birth mother. Tina was reported to have been doing drugs with her mother as well as other friends in the city that included Raymond Cormier. Tina did hard drugs such as meth, cocaine and gabapentin as well as marijuana with Raymond Cormier. Tina began selling her body for money to pay for drugs. Crime seemed to be an unavoidable aspect of Tina Fontaine's life from a young age. Tina befriended undesirable people when she came to Winnipeg. Many were involved in drugs, sexual exchanges and crimes such as theft. Raymond Cormier was one of those dangerous people. This contributed to Tina living a life of crime in the North End and Jolly stated that, "The district remained Winnipeg's dark underbelly, a hub for organized crime run by gangs" (Chapter 5). Tina was exposed to crime simply by her acquaintances and environmental surroundings. Although the city exposed Tina to crime, drugs and sexual exploitation, she grew up in Sagkeeng where, "It was impossible to grow up on the reserve untouched by domestic violence, abuse, addiction, mental illness and suicide" (Chapter 2). 
Throughout Jolly's book, betrayal is a theme of common reoccurrence. Jolly does a good job explaining how Tina's family, Child and Family Services and Law Enforcement all betrayed or let Tina down. In addition to this, Tina was betrayed by Raymond Cormier, a person whom she considered somewhat of a friend at the time. Although the police were determined to seek justice for Tina's murder, there was a specific instance where the police failed her. Tina had been picked up for suspected sexual exchanges and was let go after the police pulled a man over, failing to see that Tina had been reported as a missing person. Child and Family services had failed Tina, as well as Tina's family, by not being able to help Tina take her life down a different path. Thelma Favel had stated that when Tina was registered as missing for the last time before her death, she did not show up to her placement at the city centre hotel, "Thelma said she was not informed of this development and it wasn't until she called the agency on August 15 that she was told Tina had been officially missing for a week" (Chapter 2). This occurred only three days before Tina's body was found in the Red River. Tina's family betrayed her when they chose to let her continue her way of life in the North End with drugs, alcohol, criminals and sexual exploitation. The combinations of betrayal Tina experienced sadly played a role in the eventual outcome of her death.

Jolly's overriding theme of her book was primarily about the search for justice for Tina, her family, and all murdered Indigenous women. Sergeant O'Donovan, the Winnipeg Police Department, Tina's family, the Indigenous community and the community at large all demanded justice for Tina. Tina Fontaine made poor decisions and was exposed to a life with crime while living in Winnipeg. Tina was a young teen who made some poor decisions, however, she in no 
way deserved the abuse and trauma she went through that resulted in the loss of her life. Sergeant O’Donovan worked hard to achieve justice. He handed his supervisor Sergeant Dale McMillian a document that O’Donovan called Mr. Big, which was an undercover strategy, "It was a technique employed for investigations that had gone cold, or where a suspect had been identified but there was not enough evidence to convict." (Chapter 11). The Mr. Big was to be used on Raymond Cormier as he was the prime suspect, but the police were unable to gain concrete evidence that he had committed Tina's murder. The Indigenous community longed for justice for Tina as the growing rate of Indigenous women seemed to lack justice in not only Winnipeg but in Manitoba, as "In Manitoba, according to RCMP figures, almost half of all women murdered were Indigenous." (Chapter 1). The Indigenous community having lost so many women to murder, demanded justice be served for the victims who have lost their lives, including Tina. Jolly reviewed how Tina's family, friends and the community were all robbed of justice. Answers to so many questions were not provided, and the trial resulted in the acquittal of Raymond Cormier which was a shock to everyone.

Jolly's intentions with this book were to inform people of the truth behind Tina's story along with the reality of the struggles Indigenous women more commonly face. By sharing the stories of other Indigenous women who lost their lives in similar manners to Tina, Jolly is intending to inform the readers that this story is applicable to many families. This book was an interesting read and left the reader intrigued to find out what would happen next. It would be an interesting read for many academic audiences in the fields of Sociology, Social Work, Criminology \& Social Justice, Women's Studies or Indigenous Studies. 
One pitfall of Jolly's book is that she neglected to cover more issues with Tina's family members. The book describes how Tina was reported as a missing person numerous times, as she did not make it back before curfews to her sleeping arrangements. Tina had family members in Winnipeg who she could have been staying with. Questions about why Tina was not staying with any family, and why she was not given help for her addictions and choices could have strengthened this book. Jolly's intentions were not to dive deep into the family issues of Tina, and instead were to find out the truth of Tina's murder and seek justice. The specific issues imbedded in her family dynamics likely played a part in what happened to Tina and understanding these may help families to avoid a similar fate for their loved ones. Aside from this, the book was written very well. 